\title{
Galling Damage to Woody Ornamentals: Diagnosis and Potential Causes'
}

\author{
Adam Dale, Erin Harlow, Carrie Harmon, and Chris Marble ${ }^{2}$
}

Galling or witch's broom damage on the newly expanding buds and leaves of woody ornamental plants has become increasingly common and problematic for landscape managers and nursery growers (Figure 1). Diagnosing this damage is difficult because the most common causes are obscure or occur well before damage symptoms appear. The severity of damage and number of plants damaged ranges from a single plant to entire landscapes with dozens of plants. In many cases, several different plant species within the same landscape exhibit damage. Pest management professionals are frequently unable to confidently diagnose the cause of damage or mitigate the damage with existing pest control tools and tactics. This publication is intended to help diagnose characteristic galling damage, mitigate damage that occurs, and, when possible, prevent galling damage from occurring.

\section{Woody Plant Growth}

Plants grow through a combination of cell growth and the division of meristematic tissue, which is the origin of stem elongation, leaf development, and leaf expansion. When newly expanding leaves and stems become extremely distorted and stunted, it is frequently caused by a disruption in plant growth hormones or the pathways regulating the expression of those hormones. Therefore, when stunted growth or bud proliferation (rapid increase in number of buds) are observed on areas of new woody plant tissue, it suggests that the plant has been exposed to some trigger that disrupted the pathways that regulate meristematic tissue development. To date, the most common causes for this distorted growth on woody ornamentals are some mites, herbicides, and pathogens.

\section{Mites Associated with Characteristic Galling Damage}

An arthropod group commonly associated with distorted or stunted growth or bud proliferation, as discussed above, is microscopic mites in the family Eriophyidae (Acari: Trombidiformes) (Figure 2). This group of mites, commonly called bud, gall, blister, and rust mites, includes four to five thousand species worldwide. Eriophyid mites are extremely common and frequently found on plant tissue under close inspection with high magnification, but most species are not known to cause plant damage. These organisms are also highly dependent upon specific habitat conditions. For example, nearly all eriophyid mites feed on a narrow range of plants, either from a single plant species or genus.

1. This document is ENY-2055, one of a series of the Entomology and Nematology Department, UF/IFAS Extension. Original publication date January 2021. Visit the EDIS website at https://edis.ifas.ufl.edu for the currently supported version of this publication.

2. Adam Dale, assistant professor, Entomology and Nematology Department; Erin Harlow, county horticulture agent III, UF/IFAS Extension Columbia County; Carrie Harmon, director, UF/IFAS Plant Diagnostic Center, Department of Plant Pathology; and Chris Marble, assistant professor, Environmental Horticulture Department, UF/IFAS Mid-Florida Research and Education Center; UF/IFAS Extension, Gainesville, FL 32611.

The use of trade names in this publication is solely for the purpose of providing specific information. UF/IFAS does not guarantee or warranty the products named, and references to them in this publication do not signify our approval to the exclusion of other products of suitable composition. Use pesticides safely. Read and follow directions on the manufacturer's label.

The Institute of Food and Agricultural Sciences (IFAS) is an Equal Opportunity Institution authorized to provide research, educational information and other services

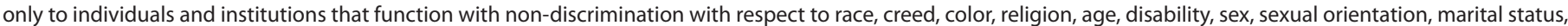

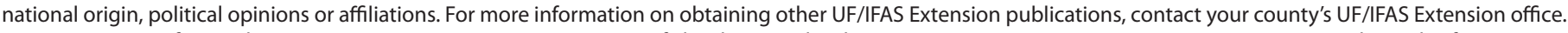
U.S. Department of Agriculture, UF/IFAS Extension Service, University of Florida, IFAS, Florida A \& M University Cooperative Extension Program, and Boards of County Commissioners Cooperating. Nick T. Place, dean for UF/IFAS Extension. 
Most species also rely on microclimatic conditions with high humidity, which typically occur under or around bud scales, the bases of leaf petioles, or depressions in leaf surfaces, or within modified plant growth or structures (galls). Therefore, the galling damage observed on woody ornamentals likely provides ideal conditions to harbor eriophyid mites and may, in some cases, be caused by them.

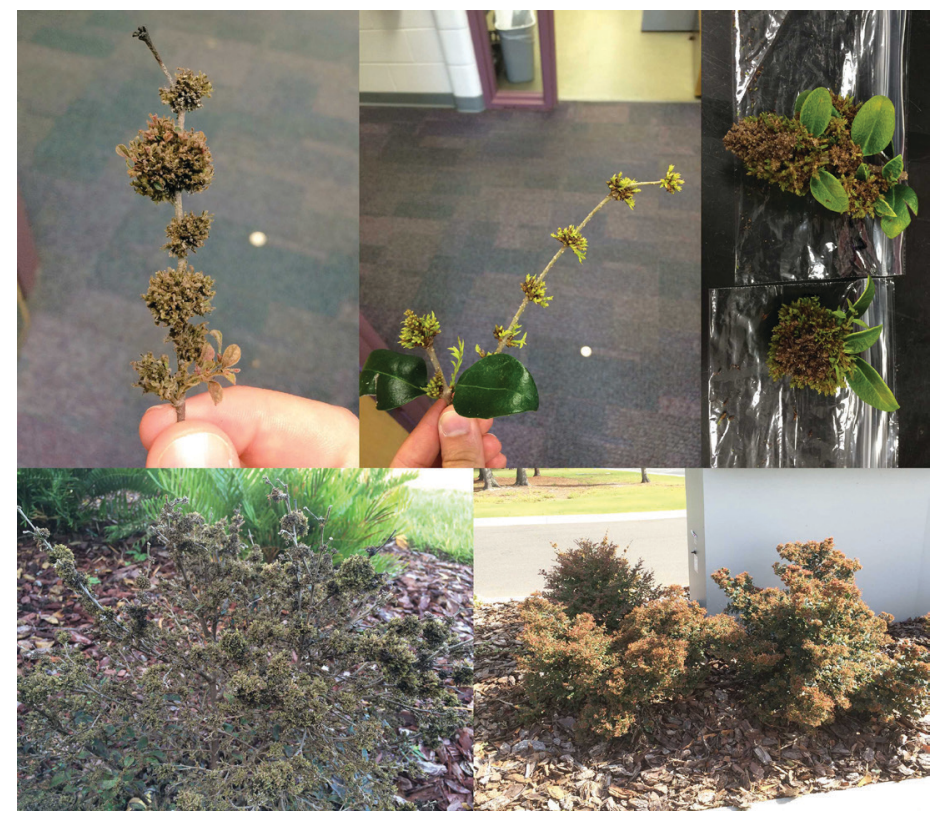

Figure 1. Images of characteristic galling damage observed in Florida landscapes to loropetalum (top left and bottom two) and ligustrum (top center, top right) from undetermined causes.

Credits: Adam Dale, UF/IFAS

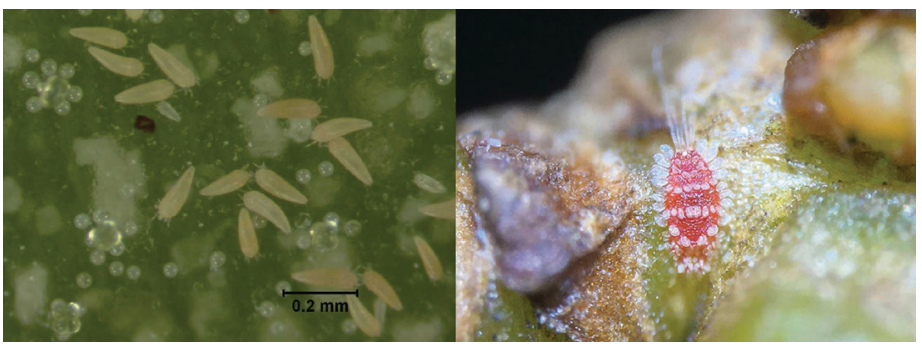

Figure 2. Images of eriophyid mites and a peacock mite. (Left) Several individual tomato russet mites (Aculops lycopersici) that resemble most eriophyid mite species. (Right) A peacock mite, Tuckerella parviformis, that was found on a symptomatic ligustrum shrub in Florida. Credits: Left, Lyle Buss, UF/IFAS; right, Matt Borden, UF/IFAS

Some eriophyid mites possess growth-regulating salivary chemicals that, when introduced to the plant during feeding, cause plant tissue to become discolored or dramatically change growth patterns and structure. Common gall-inducing eriophyid mite species known to attack woody ornamentals include Aceria lantanae on lantana, Aceria celtis on hackberry, Eriophyes parapopuli on poplar, and Eriophyes fraxiniflora on ash (Figure 3). Importantly, all modifications of plant tissue caused by eriophyid mites occur on embryonic (newly developing) plant tissue. With most gall-inducing eriophyid mites, the mites are typically found residing within the distorted plant tissue, although in some cases, they may be found farther down the plant stem where galling is not as severe. In Florida, between 2017 and 2020, the most commonly detected eriophyid mite species associated with galling damage was Aceria ligustri, a commonly found specialist on Ligustrum spp. trees and shrubs that is not known to cause damage. We may find A. ligustri most frequently because Ligustrum spp. are the most commonly submitted woody ornamentals with galling damage.

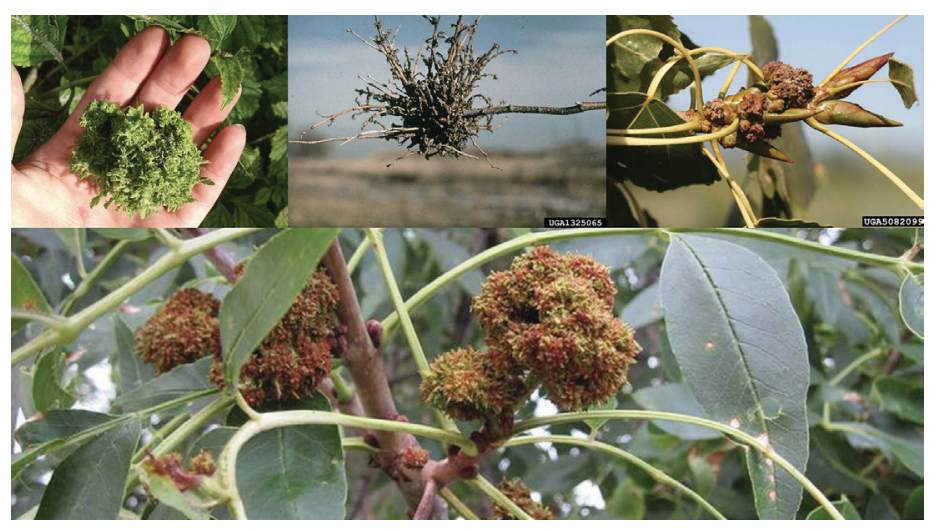

Figure 3. Characteristic galling damage to woody ornamentals caused by eriophyid mites. From top left to right, Aceria lantanae on lantana, Aceria celtis on hackberry, Eriophyes parapopuli on poplar, and Eriophyes fraxiniflora on ash.

Credits: Top left, Matt Borden, UF/IFAS; top center and right, Whitney Cranshaw, Colorado State University, Bugwood.org; bottom, Dawn Dailey O’Brien, Cornell University, Bugwood.org

A second mite group that is documented in association with galling damage to woody ornamentals, particularly Ligustrum japonicum in Florida, is peacock mites or tuckerellid mites in the family Tuckerellidae (Acari: Trombidiformes) (Figure 2). This family of mites is less commonly associated with plant damage, and especially galling damage, than eriophyid mites. However, one species, Tuckerella parviformis, was identified on multiple symptomatic L. japonicum plants in 2018 and 2019. This species has also been found on symptomatic plant samples with galling and witch's broom damage from north-central Florida as early as 1998 (Welbourn 1998). The Florida Department of Agriculture and Consumer Services Division of Plant Industry (FDACS DPI) reports records of $T$. parviformis on 20 plant species in 15 Florida counties.

In an effort to identify the cause of widespread galling damage to Florida landscape ornamentals, UF/IFAS Extension faculty and researchers have conducted a series of surveys and experiments, in part with support from the Florida Nursery Growers and Landscape Association. Unfortunately, no single common underlying cause of this damage has been identified on symptomatic woody plant 
species in Florida. Surveys of 65 symptomatic plant tissue samples from throughout Florida have found that approximately $40 \%$ (26) of submitted samples have had some level of eriophyid mite infestation, ranging from very few mites to high densities of mites. However, this association does not indicate causation, and with less than half of plants showing an association, it suggests that the mites did not cause damage in most cases.

In efforts to induce damage on asymptomatic L. japonicum, a potted plant greenhouse study was conducted in 2019. Highly symptomatic L. japonicum plant tissue heavily infested with eriophyid mites (Aceria ligustri) and peacock mites (Tuckerella parviformis) was collected from several different symptomatic plants in a commercial landscape in north-central Florida. Four experimental treatments were set up on the asymptomatic potted plants: (1) infested with mites, (2) infested with symptomatic plant tissue, (3) leaves inoculated with macerated symptomatic tissue, and (4) not infested with anything (control). Plants were monitored weekly for 13 months, but no treatment resulted in an onset of symptoms. Based on this study, it appears that some factor in addition to or other than the mites is required to induce galling damage on asymptomatic Ligustrum spp. plants.

\section{Herbicides Associated with Similar Damage}

By definition, herbicides interfere with plant growth and physiology, with the goal of plant death or growth inhibition. Thus, it should be no surprise that herbicide use comes with the risk of non-target unintended effects on desirable plants.

Several herbicide classes can pose risks to woody ornamentals. The most recent example being metsulfuron, which can cause severe damage to large oak trees if applied improperly. Glyphosate can also damage woody plants if applied improperly. The most common herbicide class associated with galling and witch's broom damage to woody ornamentals is the class of herbicides that inhibit acetolactate synthase, commonly referred to as ALS inhibitors. These include the sulfonylurea herbicides (e.g., metsulfuron, halosulfuron, etc.) and imadizolinones. While herbicides from either of these ALS-inhibiting chemical families can cause damage to ornamental plants, galling and witch's broom damage is predominately associated with the imadizolinone class of herbicides.

Imidazolinone herbicides include: imazamox, imazapyr, imazethapyr, imazapic, and imazaquin. In the landscape pest control industry, the most commonly used commercial herbicides in this group include imazaquin (Scepter ${ }^{\circledast} \mathrm{T} \& \mathrm{O}$ ) and imazethapyr, which is a component of some herbicide mixtures such as Dismiss ${ }^{\oplus}$ South. There are also several homeowner products available at big-box retailers such as RoundUp ${ }^{\otimes} 365$, Ortho Groundclear ${ }^{\oplus}$, and others that may contain low concentrations of imazethapyr, imazapic, or imazapyr. Of all of these herbicides, imazaquin is the only herbicide that is labeled for use around the base of woody plants but can only be applied around ornamentals listed on the label. Products containing imidazolinone active ingredients can be very risky to use around the base of woody plants because they are root-absorbed and have a long half-life, meaning they can stay in the soil and remain available for uptake for several months. If woody plants are exposed to these compounds, they can exhibit severe damage, ranging from reduced leaf size, over-proliferation and stunting of buds, and severe growth inhibition (Figure $4)$.

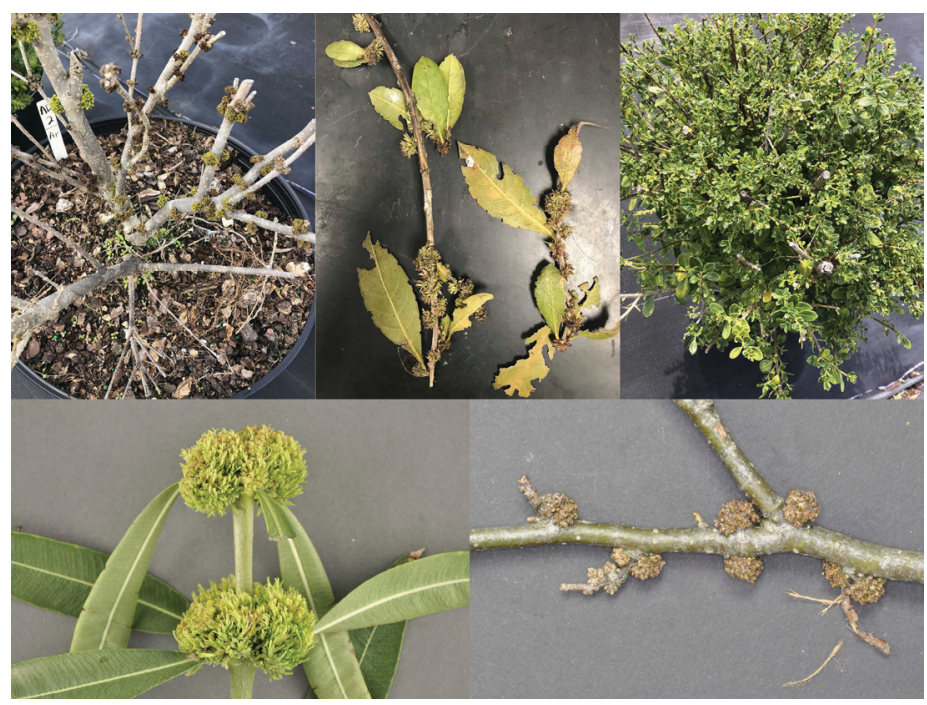

Figure 4. Damage caused by imazapyr exposure from herbicide applied to the soil near the base of the plant or in the root zone. Pictured clockwise, starting in the top left are canopy tissue from ligustrum, green buttonwood, dwarf Schillings holly, oleander, and linden.

Credits: ligustrum and holly were taken by Chris Marble, UF/IFAS. Photograph of green buttonwood was taken by Adam Dale, UF/IFAS. Photos of oleander and linden were provided by the F.A. Bartlett Tree Expert Company

In almost every case in which these herbicides have caused damage to ornamental plants, they were applied incorrectly or off-label. With the exception of imazaquin, which is labeled for use in and around certain ornamentals, none of these herbicides should be applied in landscape planting beds or in close proximity to ornamentals. When choosing an herbicide, it is important to read the entire label. There have been many instances in which these herbicides were applied to landscape beds or around trees that were 
mulched with gravel or rock, because some of the labels may allow application to graveled areas. However, the labels will also state that they should not be applied within the root zones of desirable plant species, which often extends well beyond the canopy of the tree or shrub. A careful review of the label prior to application could have prevented the damage in these cases. Additionally, this class of herbicides can remain active in the soil for several months.

\section{Plant Pathogens Associated with Similar Damage}

Certain bacteria, fungi, and viruses can cause plant tissues to proliferate and develop unusual growth. These can be difficult to diagnose in the field and usually require lab tests to confirm.

The bacterium Rhizobium radiobacter (formerly Agrobacterium tumefaciens) is the causal agent of the well-known crown gall disease of many plants around the world. The bacterium, which is a common inhabitant of soil, infects more than 90 plant families through wounds and causes galls on roots and stems near the soil line ("crown" tissue) (Figure 5). These galls interrupt normal vascular movement of water and nutrients, causing plant decline and occasionally girdling the stem of the plant and killing it. Although we see crown gall on woody plants primarily, the bacterium can also infect herbaceous plants. Because the bacterium can survive long periods in the soil, removal of the whole infected plant is recommended. When replanting into an area known to have had crown gall disease, take special care to avoid wounding the roots and stems of the new plant, to avoid infection. Large-scale plantings, propagation units, and nurseries may benefit from incorporating a pre-plant root dip of commercially available biological control agents comprised of a related, but non-pathogenic, strain of the bacterium. Sanitize pruning, propagation, and planting tools between plants in areas where galls have been noted, and discard infected plants away from the property.

Phytoplasmas, which are bacteria that live only inside a plant or an insect vector, can cause plant distortion such as "mouse-ear," shoot proliferation, and witch's broom. Phytoplasma diseases are more common in herbaceous plants but have been diagnosed in some woody plants as well. In Florida, the most well-known phytoplasma disease of a large ornamental plant causes decline and death of palms (lethal bronzing disease). The plant disease diagnostic lab in Gainesville, Florida, has had very few positive identifications of phytoplasmas in woody ornamentals but many positive detections in herbaceous plants.
Because the bacterium cannot be cultured, only a test for the phytoplasma DNA will confirm the presence of the pathogen. Prevention of infection is key because there is no cure for phytoplasma infections. Remove known-infected plants from a property immediately after they are detected. The phytoplasma does not survive in the soil, but if infected plants are still nearby, new plantings could become infected.

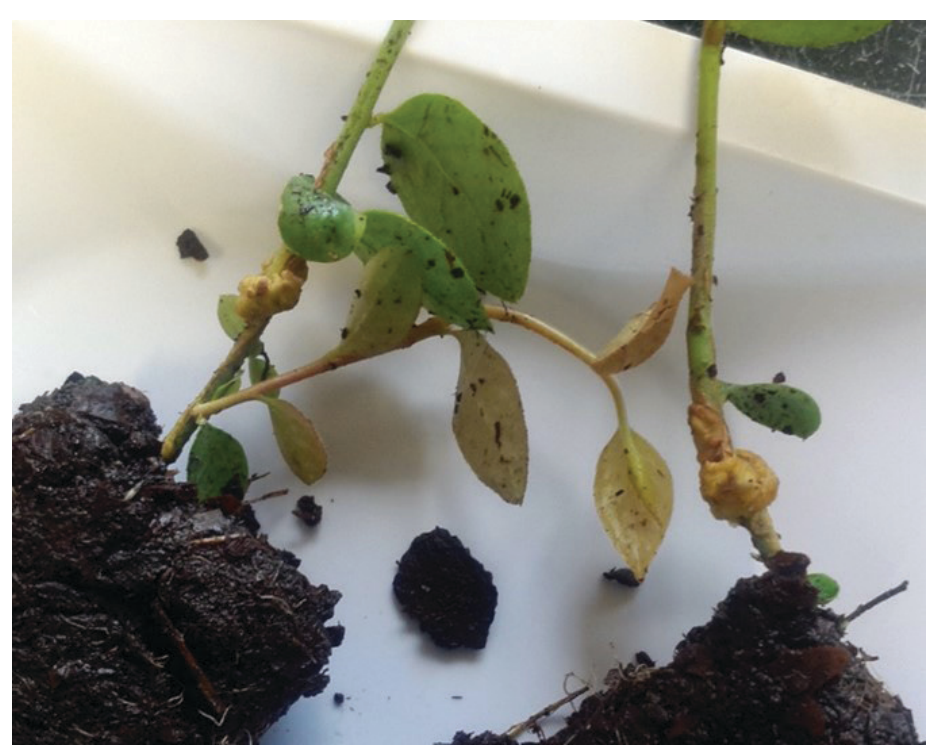

Figure 5. Crown gall on rooted cuttings of southern highbush blueberry stems.

Credits: UF/IFAS Plant Diagnostic Center, 2012

Sphaeropsis tumefaciens is a fungus that can cause galls and shoot proliferation in woody plants in Florida (Figure 6). The fungus is common, and disease appears to be related to water stress, causing more dieback and plant death when warm, wet weather follows periods of drought. Infection will cause swelling beneath the bark, which then cracks and reveals the fungal fruiting structures (pycnidia) (Figure 7). Swollen tissues can give rise to witch's broom symptoms as the shoots proliferate and elongate (Figure 8). Infection can also girdle twigs and branches, causing dieback. The fungus is spread by water splash, entering the plant through wounds, especially pruning wounds. Witch's broom and gall symptoms can be pruned out by cutting 12 " or more beneath the swelling, pruning back until the vascular tissue is healthy. However, this is unlikely to eliminate the infection, especially in large specimens or closely planted hedges, where abundant inoculum and susceptible plant tissue are available.

Although viruses are known to cause deformed growth in many plants, it is rare to find viruses in woody plants, and there have been no diagnoses in the UF/IFAS Plant Diagnostic Center of galling in woody plants caused by viruses. Discolored shoots, vegetative growth where there should be flowers, epinasty (plant part is bent outward or 
downward), and bud necrosis (death) are all virus symptoms. For example, a new virus in roses causes rose rosette disease. Although galls are not a symptom, unusual growth, red leaves, and excessive thorniness of stems are symptoms. These plants should be immediately removed and destroyed to prevent spread of the infection to new plants.

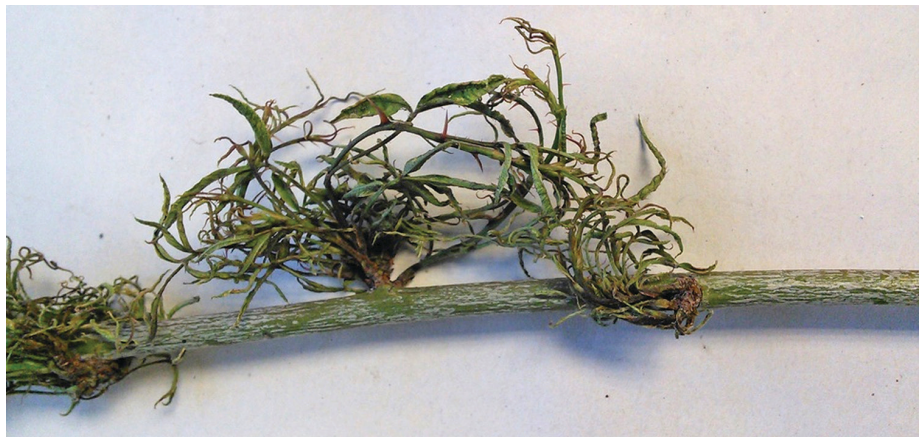

Figure 6. Shoot proliferation at the buds on a rose plant stem. Credits: UF/IFAS Plant Diagnostic Center, 2018

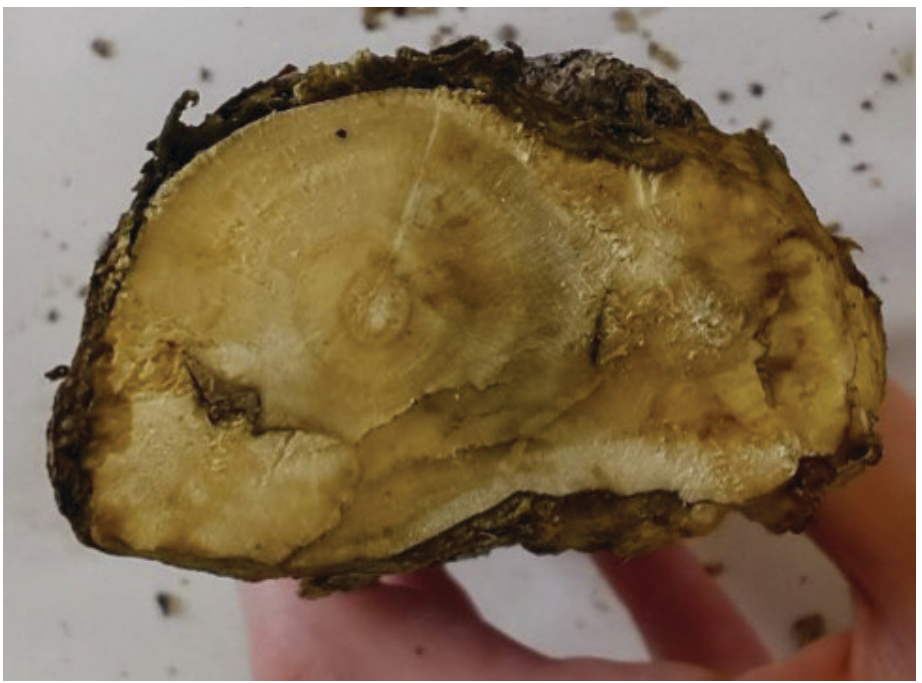

Figure 7. Vascular discoloration and disorganization on a holly branch. Branch is swollen and bark has split. Sphaeropsis tumefaciens was cultured from the discolored areas.

Credits: UF/IFAS Plant Diagnostic Center, 2015

\section{Management Recommendations}

Although there appears to be no single cause of this characteristic galling damage on woody ornamentals throughout Florida and other regions of the United States, it is known that some mites, certain commonly used herbicides, and some pathogens can be associated with the damage. Below are a few guidelines to follow to ensure that your landscape management practices are not the underlying cause.

1. Do not apply imazidolinone herbicides within the root zone of any desirable landscape plant, and closely read and follow any herbicide's label instructions.

\section{Avoid repeated broad-spectrum (contact-toxic to mul-} tiple insect types) insecticide applications to the canopy of woody plants because this has been associated with mite and other pest outbreaks due to widespread mortality of predatory organisms.

3. Keep detailed records of all pesticides that were applied to the property. This includes applications made by pest control professionals and any applications made by homeowners. Knowing what pesticides were applied can help diagnose and correct any issues that may arise.

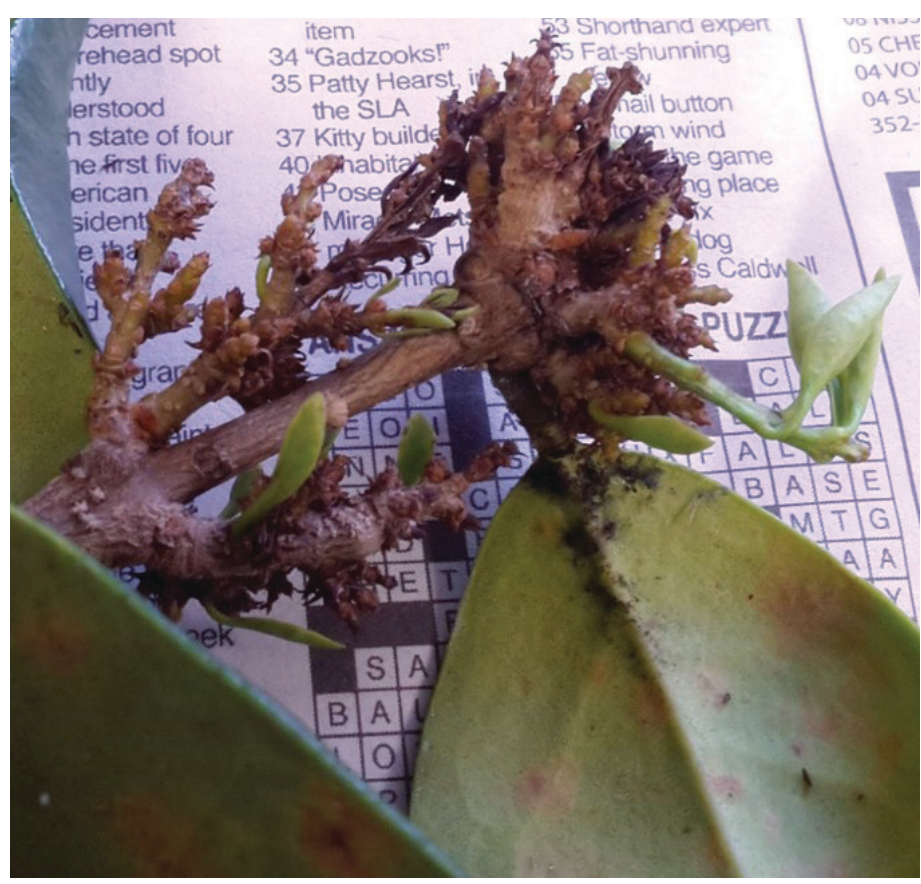

Figure 8. Bud proliferation on a ligustrum sample. Sphaeropsis tumefaciens was cultured from the stems of this sample. Sap-feeding insects were also observed and caused the sooty mold apparent in the photo.

Credits: UF/IFAS Plant Diagnostic Center, 2013

\section{If You See Damage}

1.If you suspect eriophyid mites, prune symptomatic tissue, including a few inches of asymptomatic tissue towards the main trunk. Place the sample with damage down, into a vial or jar and keep cool until it can be filled with $80 \%$ alcohol and sealed shut (Figure 9). Alternatively, place the pruned tissue into a sealed paper envelope. Ship the sample to the appropriate UF/IFAS diagnostic lab for processing and identification.

\section{If you suspect herbicide damage, high-quality photos} of symptomatic plants can be very helpful in diagnosis. However, in many cases the only definitive way to diagnose herbicide injury is to collect and submit plant tissues to a diagnostic lab that offers pesticide residue analysis. The amount of tissue required, handling, and submission process will differ depending upon the laboratory and 
diagnostic method; please contact the individual lab before submitting a sample.

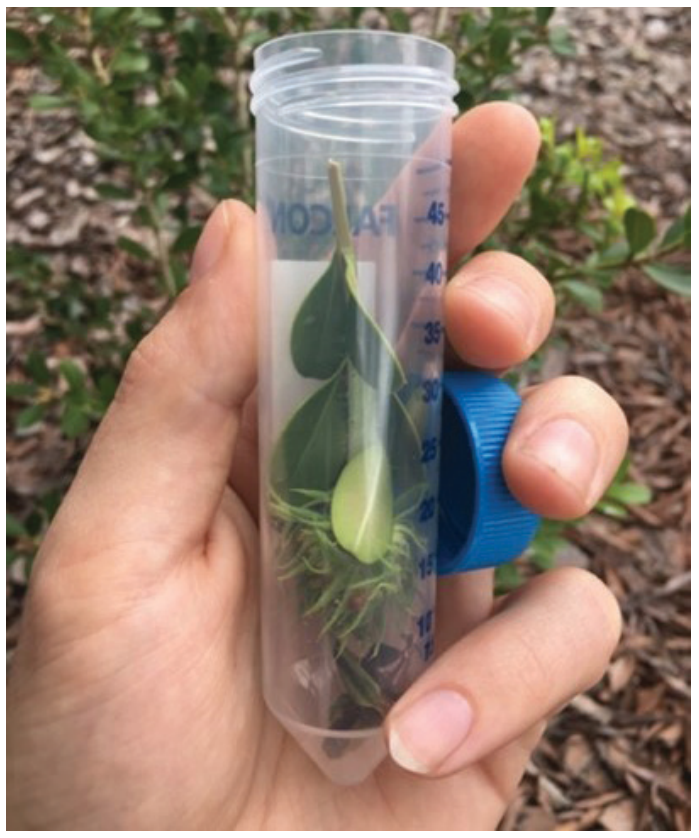

Figure 9. Image of symptomatic tissue collection and preservation for submission to diagnostic labs.

Credits: Matthew Borden, UF/IFAS

3. Reduce environmental stress when possible. Ensuring that plants are being irrigated, fertilized, and maintained correctly can help them recover from many kinds of biotic and abiotic stresses. In many cases, established trees or shrubs can eventually recover from herbicide or other types of injury over time if they are cared for properly.

4. If plant death or otherwise unrecoverable injury occurs, avoid immediately re-planting the area. ALS-inhibiting and certain other herbicides have a long soil residual activity, and planting another valuable landscape plant into contaminated soil could cause additional injury. Before replanting, it is important to get a diagnosis or rule out herbicide damage as the likely cause. As an alternative to laboratory analysis, you may wish to conduct a simple soil bioassay to get an inexpensive (but less accurate) estimate of herbicide contamination. To conduct a bioassay for ALS-inhibiting herbicides, collect soil from the suspected contaminated area in addition to soil where no injury has been observed. Place the soil samples in different pots and seed them with tomato seeds. When seedlings emerge, inspect them for injury by comparing them to the seedlings in the uncontaminated soil. If leaves are malformed, stunted, or deformed, it may not be safe to re-plant. For the most accurate and reliable recommendations, however, it is best to contact your county UF/IFAS Extension agent or use the resources listed below.
5. In cases where individual branches or regions of the plant are damaged, the most effective option is to prune off damaged tissue and care for the plant with proper irrigation, fertilization, and maintenance practices to promote growth and recovery. For cases where entire trees or shrubs are damaged, the only option for recovery is to avoid any subsequent herbicide applications around the plant and wait for new, asymptomatic tissue to develop, which may take several months to more than a year.

6.If severe mite infestations are documented in association with the damage on plants of interest, then applying miticides labeled for eriophyid mite control may be warranted. It is important to confirm that eriophyid mites are listed on the label, and not just mites or other mite groups. Examples of miticide active ingredients labeled for eriophyid mite control on ornamental plants include fenpyroximate, abamectin, chlorfenapyr, spiromesifen, spirotetramat, fenazaquin, carbaryl, and insecticidal soap. Be sure to read the label and confirm that a given product is appropriate for the site.

\section{Resources for Diagnostic Assistance}

Plant pest diagnostic services are an extremely valuable resource provided by UF/IFAS Extension throughout Florida, serving thousands of people annually to help diagnose and solve plant and pest problems. UF/IFAS county Extension offices are the local resource to provide short-term diagnosis and solutions. When needed, there are also several specialized diagnostic centers around the state that provide quick and accurate pest diagnoses. The pest diagnostic hub with access to all UF/IFAS diagnostic services can be found at https://diagnostics.ifas.ufl.edu. A regional UF/IFAS plant diagnostic lab directory can also be found at https:// plantpath.ifas.ufl.edu/extension/diagnostic-labs/. 